\title{
COMPARISON OF HARMONIC SCALPEL VERSUS CONVENTIONAL HEMOSTASIS IN THYROID SURGERY IN TERMS OF PER- OPERATIVE AND POSTOPERATIVE OUTCOME.
}

\footnotetext{
1. MBBS

Registrar Surgery

Govt Teaching Hospital Shahdara, Lahore.

2. FCPS

Assistant Professor Surgery Govt Teaching Hospital Shahdara, Lahore.

3. FCPS

Assistant Professor Cardiology Sahara Medical College Narowal.

4. MBBS

Registrar

Department of ENT

Jinnah Hospital, Lahore.

5. MBBS

Medical Officer

Department of Surgery

Govt Teaching Hospital Shahdara

Lahore.

6. FCPS

Senior Registrar Surgery

Gujranwala Medical College.
}

Correspondence Address:

Dr. Mudassar Murtaza

$339 \mathrm{E}$ Block Johar Town Lahore.

drmudassirmurtaza@gmail.com

Article received on:

12/02/2019

Accepted for publication:

$27 / 06 / 2019$
Mumtaz Ali ${ }^{1}$, Mudassar Murtaza ${ }^{2}$, Mohammad Aleem-ud-Din ${ }^{3}$, Mohammad Burhan ud Din ${ }^{4}$, Assam Sarwar ${ }^{5}$, Ansar Aslam ${ }^{6}$

ABSTRACT: Harmonic scalpel is popular for use in a variety of surgical procedures including thyroid surgery. Proposed advantages of the harmonic scalpel include less lateral thermal tissue damage with no electrical energy transferred to the patient, no neuromuscular stimulation, less smoke formation as compared with electrocautery. Objectives: Our aim was to compare outcomes following thyroid surgery in terms of operative time, postoperative pain, drainage volume, recurrent laryngeal nerve and parathyroid gland injury with the use of the Harmonic Scalpel compared to conventional methods of hemostasis. Study Design: Randomized control trial. Setting: Surgical Department Lahore General Hospital. Period: Twelve Months June 2016 to June 2017. Material \& Methods: 60 patients, 30 in each group. Patients were randomized in each group by balloting method. Operative time, postoperative pain and drainage volume was assessed during hospital stay. Recurrent laryngeal nerve and parathyroid gland injury was assessed during hospital stay and follow-up. Results: There was no significant difference in development of hoarseness of voice in both groups, $p$-value $>0.05$. The mean operative time for group A was $69.47 \pm 15.44$ minutes and for group B it was $54.93 \pm 11.56$ minutes, $p$-value $<0.05$. The overall blood loss in group-A and group-B was $118.73 \pm 50.72 \mathrm{ml}$ and $44.60 \pm 10.70$ $\mathrm{ml}, \mathrm{p}$-value $<0.05$. The mean post-op pain observed at $2^{\text {nd }}$ day for group $B$ was $2.93 \pm 3.57$ and for group A it was 3.57 \pm 0.77 , p-value < 0.05. Conclusion: Use of Harmonic Scalpel has better results in thyroid surgery in terms of less operative time, less postoperative pain, less drainage volume, while no RLN \& parathyroid injury detected in either group.

Key words: $\quad$ Blood Loss, Harmonic Scalpel, Laryngeal Nerve Injury, Open Surgery, Pain, Thyroidectomy.

Article Citation: Ali M, Murtaza M, Aleem ud Din M, Din MB, Sarwar A, Aslam A. Comparison of Harmonic Scalpel versus conventional hemostasis in Thyroid surgery in terms of per-operative and postoperative outcome. Professional Med J 2020; 27(1):68-73. DOI: 10.29309/TPMJ/2020.27.1.3278

\section{INTRODUCTION}

Surgery of thyroid gland has accomplished a distinguished fabulousness shown by fast convalescence and a negligible rate of complications, with the goal that thyroid operation is now conveniently performed on day case basis. ${ }^{1}$ The suture knotting and use of clips were commonly applied to secure hemostasis. Diathermy and recently, the Harmonic Scalpel (HS) are other ways. ${ }^{2}$

Bleeding in thyroid surgery can cause lifethreatening airway compromise and hemorrhage. Identification of recurrent laryngeal nerve (RLN) and parathyroids can be difficult in the presence of hemorrhage. New modalities of hemostasis are expected to achieve rapid and effective control of hemorrhage. ${ }^{3}$

Lessening of the time spent to ligate and divide these vessels with the conventional knot-tie method can considerably diminish the operative time in this technique. This will both diminish the operative time and the operative costs. ${ }^{4}$

Use of HS became popular in various surgical procedures. Anticipated benefits of this device comprise minimum lateral heat injury with no current transmitted to the body associated with diathermy. The utilization of bipolar sealing systems and the Harmonic Scalpel are now gaining importance in lessening the duration of surgery and diminished hemorrhage, while holding a high safety profile. ${ }^{5}$ 
Our study is aimed to compare the relative outcomes following thyroid surgery regarding the drain output, operative duration, postoperative pain, recurrent laryngeal nerve and parathyroid gland injury with the use of the Harmonic Scalpel (HS) compared to conventional methods of hemostasis.

\section{Operational Definitions}

Operative Time was counted in minutes from flap raising to skin closure. Drainage volume: was defined as amount of blood collected peroperatively by pre-weighed sponges and suction chamber. Postoperatively it was measured via suction drain placed in the wound. It was measured in (ml) starting from application of skin stitches till 48 hours after surgery.

We hypothesized that there is significant difference regarding the use of HS versus Conventional hemostasis in thyroid surgery regarding reduction of operative time, drainage volume, postoperative pain and injuries to Parathyroids and Recurrent Laryngeal Nerve.

\section{MATERIALS AND METHODS}

This Randomized Control Trial was done at Surgical Department, Lahore General Hospital from June 2016 to June 2017. Sampling was done by randomization by balloting method .Sixty patients were put in two equal groups of 30 each. Sample size was calculated by formula keeping the power of study equal to $95 \%$ confidence level. Patients of age 18-60 years with benign thyroid disease, including nodule, multi nodular goiter, thyroid cyst, toxic adenoma were included and all the patients with carcinoma thyroid, recurrent thyroid swelling, neck dissection and exceptionally large goiter were excluded.

An informed consent was obtained and patients were allocated in conventional hemostasis $(\mathrm{CH})$ Group A and Harmonic scalpel (HS) Group B by balloting method.

Operative time, per-operative and post operative blood loss, drainage volume, postoperative pain, recurrent laryngeal nerve injury and parathyroid gland injury were compared between the two groups. Data was recorded on especially designed performa.

\section{Pre-operative Preparation and Surgical Technique}

After history \& examination, baseline investigations, ECG, Chest X-ray, X-ray thoracic inlet, thyroid functions tests, thyroid ultrasound, FNAC \& indirect laryngoscopy done. Thyroid scan was done in selected patients. Patients were subjected to anesthesia and cardiology assessment.

After general anesthesia proper positioning, monitoring, and draping done by the standard way 4 to $6 \mathrm{~cm}$ Kocher's incision made. In Group A superior \& inferior thyroid vessels ligated by $2 / 0$ vicryl sutures and rest of the vessels with absorbable 4/0 vicryl sutures and/or diathermy by conventional method.

In group B all the vessels were sealed by using the FOCUS Harmonic Scalpel. Superior and inferior thyroid vessels ligated with HS twice in two succeeding areas of vessel. HS was used just to coagulate the distal part of the artery. We cut the tissue in proximal part. Remaining steps in surgery were same for the two groups. Identification of recurrent laryngeal nerve and parathyroids was done in every case. Radivac drain used under the strap muscles was taken away within $1^{\text {st }} \& 2^{\text {nd }}$ postoperative day. Strap muscles and platysma were closed with Vicryl 4/0 absorbable sutures. Skin closure done subcutically with prolene $3 / 0$. Postoperatively vocal cords motility was assessed by laryngoscopy at the time of extubation.

First three variables, operative time, drainage volume, postoperative pain was assessed during the hospital stay.

RLN injury was identified with mobility of vocal cords tested at the time of extubation. During the hospital stay any change in the voice quality was recorded. Follow up was done on $7^{\text {th }}$ and $14^{\text {th }}$ postoperative days. Further follow-up was done at monthly interval for two months.

Parathyroid injury was assessed by clinically 
with development of perioral numbness, tingling and tetany within 48 hours after surgery and biochemical parameters include assessment of serum calcium levels $<8.0 \mathrm{mg} / \mathrm{dl}$ on postoperative days, $1^{\text {st }}, 2^{\text {nd }}, 7$ th, $14^{\text {th }}$ and 1 Month on follow up. Patient was assessed post-operatively for pain using visual analogue scoring system till 48 hours after surgery.

\section{Data Analysis}

Data analysis was performed using SPSS version 21. Values were summarized as mean $( \pm S D)$ for continuous variables (age). Frequencies and percentages were calculated for categorical variables. Differences in the proportions were tested with chi-square (x2) test. A significant difference was considered present when $\mathrm{p} \leq$ 0.05 .

\section{RESULTS}

In all patients mean age of cases was $33.55 \pm 10.18$ years whereas in group-A mean age was $36.20 \pm 10.98$ years and in group-B mean age was $31.50 \pm 8.89$ years with no significant difference, p-value $>0.05$.

Comparison of Hoarseness of voice

\begin{tabular}{|c|c|c|c|c|c|}
\hline & \multicolumn{2}{|c|}{ Study Group } & \multirow{2}{*}{ Total } & \multirow{2}{*}{ P-Value } \\
\hline & & Group A & Group B & & \\
\hline \multirow{2}{*}{$\begin{array}{l}\text { Hoarseness } \\
\text { of voice } \\
\text { 1st day }\end{array}$} & Yes & $\begin{array}{c}2 \\
(6.67 \%)\end{array}$ & $0(0 \%)$ & $\begin{array}{c}2 \\
(3.33 \%)\end{array}$ & \multirow{3}{*}{0.15} \\
\hline & No & $\begin{array}{c}28 \\
(93.33 \%)\end{array}$ & $\begin{array}{c}30 \\
(100 \%)\end{array}$ & $\begin{array}{c}58 \\
(96.67 \%)\end{array}$ & \\
\hline \multicolumn{2}{|l|}{ Total } & $\begin{array}{c}30 \\
(100 \%)\end{array}$ & $\begin{array}{c}30 \\
(100 \%)\end{array}$ & $\begin{array}{c}30 \\
(100 \%)\end{array}$ & \\
\hline
\end{tabular}

In group- A 2 patients developed hoarseness of voice at $1^{\text {st }}$ post-operative day while in group-B none of the patients had hoarseness of voice postoperatively. Moreover none of cases in either group had hoarseness of voice after $1^{\text {st }}$ postoperative day.

The mean operative duration for group $A$ was $69.47 \pm 15.44$ minutes and for group $B$ it was $54.93 \pm 11.56$ minutes. In Group B it was lower significantly ( $p$-value $<0.05$ ). In group $B$ intra operative, postoperative and overall blood loss was lower when compare to group-A, p-value <
0.05 .

The mean post-op pain observed at $1^{\text {st }}$ day for group $B$ was $4.43 \pm 0.504$ and for group A was $5.50 \pm 0.820$, while at $2^{\text {nd }}$ day for group $B$ was $2.93 \pm 0.583$ and for group $A$ it was $3.57 \pm$ 0.77 . The mean pain after operation was more in conventional group at both postoperative measurements, $\mathrm{p}$-value $<0.05$.

\begin{tabular}{|c|c|c|c|c|}
\hline & & Mean & S.D & P-Value \\
\hline \multirow{3}{*}{$\begin{array}{l}\text { Operative } \\
\text { time } \\
\text { (minutes) }\end{array}$} & Group A & 69.47 & 15.44 & \multirow{3}{*}{$<0.001$} \\
\hline & Group B & 54.93 & 11.56 & \\
\hline & Total & 62.20 & 15.38 & \\
\hline \multirow{3}{*}{$\begin{array}{l}\text { Blood loss } \\
\text { intra-Op }(\mathrm{ml}\end{array}$} & Group A & 49.07 & 21.35 & \multirow{3}{*}{$<0.001$} \\
\hline & Group B & 25.77 & 7.84 & \\
\hline & Total & 37.42 & 19.81 & \\
\hline \multirow{3}{*}{$\begin{array}{l}\text { Blood loss } \\
\text { post-Op } \\
(\mathrm{ml})\end{array}$} & Group A & 69.67 & 31.09 & \multirow{3}{*}{$<0.001$} \\
\hline & Group B & 18.83 & 5.36 & \\
\hline & Total & 44.25 & 33.85 & \\
\hline \multirow{3}{*}{$\begin{array}{l}\text { Total blood } \\
\text { loss (ml) }\end{array}$} & Group A & 118.73 & 50.72 & \multirow{3}{*}{$<0.001$} \\
\hline & Group B & 44.60 & 10.70 & \\
\hline & Total & 81.67 & 52.13 & \\
\hline \multirow{2}{*}{$\begin{array}{l}\text { Post-Op } \\
\text { pain 1st day }\end{array}$} & Group A & 5.50 & 0.820 & \multirow{2}{*}{$<0.001$} \\
\hline & Group B & 4.43 & 0.504 & \\
\hline \multirow{2}{*}{$\begin{array}{l}\text { Post op } \\
\text { pain on } 2^{\text {nd }} \\
\text { day }\end{array}$} & Group A & 3.57 & 0.77 & \multirow{2}{*}{$<0.001$} \\
\hline & Group B & 2.93 & 0.583 & \\
\hline \multirow{2}{*}{$\begin{array}{l}\text { Serum } \\
\text { calcium 1st } \\
\text { day }\end{array}$} & Group A & 8.29 & 0.40 & 0.627 \\
\hline & Group B & 8.34 & 0.28 & \\
\hline \multirow{2}{*}{$\begin{array}{l}\text { Serum } \\
\text { calcium 2nd } \\
\text { day }\end{array}$} & Group A & 8.56 & 0.27 & 0.064 \\
\hline & Group B & 8.67 & 0.18 & \\
\hline \multirow{2}{*}{$\begin{array}{l}\text { Serum } \\
\text { calcium 7th } \\
\text { day }\end{array}$} & Group A & 8.84 & 0.44 & \multirow{2}{*}{0.202} \\
\hline & Group B & 8.98 & 0.38 & \\
\hline \multirow{2}{*}{$\begin{array}{l}\text { Serum } \\
\text { calcium } \\
\text { 14th day }\end{array}$} & Group A & 8.78 & 0.30 & \multirow{2}{*}{0.341} \\
\hline & Group B & 8.87 & 0.41 & \\
\hline \multirow{2}{*}{$\begin{array}{l}\text { Serum } \\
\text { calcium 1st } \\
\text { month }\end{array}$} & Group A & 8.84 & 0.20 & \multirow{2}{*}{0.78} \\
\hline & Group B & 8.86 & 0.26 & \\
\hline
\end{tabular}

Table-I. Comparison of operative different variables in both study groups 
The mean serum calcium level done at Day 1 and on further follow up was statistically same in both study groups, p-value $>0.05$.

Comparison of cases in each Group

\begin{tabular}{|l|c|c|c|}
\hline \multirow{2}{*}{ Left Lobectomy } & \multicolumn{2}{|c|}{ Study Group } & \multirow{2}{*}{ Total } \\
\cline { 2 - 4 } & Group A & Group B & \\
\cline { 2 - 4 } & 7 & 2 & 9 \\
\hline \multirow{2}{*}{ Right Lobectomy } & 1 & $6.7 \%$ & $15.0 \%$ \\
\cline { 2 - 4 } & $3.3 \%$ & $10.0 \%$ & $6.7 \%$ \\
\hline Near Total & 2 & 0 & 2 \\
\hline Thyroidectomy & $6.7 \%$ & $.0 \%$ & $3.3 \%$ \\
\hline Right lobectomy & 11 & 6 & 17 \\
\cline { 2 - 4 } \& Isthmectomy & $36.7 \%$ & $20.0 \%$ & $28.3 \%$ \\
\hline Subtotal & 9 & 19 & 28 \\
\hline thyroidectomy & $30.0 \%$ & $63.3 \%$ & $46.7 \%$ \\
\hline
\end{tabular}

Chi-square $=10, \mathrm{p}$-value 0.029

\section{DISCUSSION}

Since Kocher and Billroth initially depicted an adequate method of a standardized thyroid surgery in Nineteenth century, thyroid surgery has become very common operation in general surgery and bilateral total/ near total thyroidectomy is undertaken in many thyroid disorders. ${ }^{6}$ Owing to ample vascular network of thyroid gland, careful hemostasis is compulsory for clean field and to abandon iatrogenic injury of nearby important structures, with prevalence of $1.75 \%$ concerning recurrent laryngeal nerve (RLN) and hypoparathyroidism up to $18 \%{ }^{7}$

A study reported that mean age in Harmonic Scalpel (HS) group and in Conventional Hemostasis $(\mathrm{CH})$ group was 43 and 37 years. They reported there were $13(15.29 \%)$ male and $72(84.71 \%)$ female cases. ${ }^{8}$ Another study reported that mean age in $\mathrm{CH}$ and $\mathrm{HS}$ was $50.1 \pm 19.3$ years and $48.5 \pm 21.8$ years with male / female ratio as 323/66 in $\mathrm{CH}$ and 332/57 in HS group. The age and gender distribution was statistically same in both groups, p-value $>0.05 .^{9}$ We also found mean age in $\mathrm{CH}$ was $36.20 \pm 10.98$ years and in HS mean age was $31.50 \pm 8.89$ years with no significant difference, $p$-value $>0.05$. There were $4(13.33 \%)$ males and $26(86.67 \%)$ females in group A while in there were 5(16.67\%) male and $25(83.33 \%)$ females in group B. The age and gender distribution was statistically same in both groups, $\mathrm{p}$-value $<0.05$. The above studies have reported higher mean age while in our study age distribution was in mid 30's; the overall mean age in all patients was $33.55 \pm 10.18$ years.

During thyroid surgery, hemostasis may be achieved with standard suture tying technique or with diathermy; these two methods are commonly used to control hemorrhage. As Knotting takes a little more timeand knots can be slipped, diathermy furthermore is a displeasing choice because it has the possible threat of damaging adjacent tissues from dispersal of heat. ${ }^{10}$ Use of harmonic scalpel can reduce the duration of operation by using its unique functions of coagulation and cutting at the same time. ${ }^{11}$ initially it was used only in minimal invasive surgery but the device may prove its benefits in terms of reduced operative duration. It has also shown effectiveness in thyroid surgery outcomes, head and neck, chest and abdominal surgery. ${ }^{12}$

In 2014 a research reported that in mean operative time was $44.9 \pm 8.3$ in HS and was $69.5 \pm 10.7$ in conventional group, with significantly lower mean operative time, $\mathrm{P}<.001 .{ }^{8}$ One more study reported that surgical time, $\min ($ mean $\pm S D)$ was $125 \pm 30.4$ and $79 \pm 21.5$ in $\mathrm{CH}$ and HS group, $\mathrm{P}$ value $<0.001 .{ }^{9}$ Another study favored $\mathrm{HS}$ in terms of less mean operative time and pain i.e. Mean operative time (40mins vs. 46.7$) \cdot{ }^{13}$ Mean operative time in our trials for $\mathrm{CH}$ was $69.47 \pm 15.44$ minutes and for HS it was 54.93 \pm 11.56 minutes. Group $B$ had remarkably lower operative duration when compared to group $A, p$-value $<0.05$. We and all above studies are in favor of HS due to less operative time.

In another study the amount of blood loss was much less for HS group. It was $403 \mathrm{ml}$ in the control group and $260 \mathrm{ml}$ in harmonic group $(p=0.08) .{ }^{11}$ We found that overall blood loss in group $A$ and group B was $118.73 \pm 50.72 \mathrm{ml}$ and $44.60 \pm 10.70$ $\mathrm{ml}, \mathrm{p}$-value $<0.05$. In group-B intra, post op and overall group-B had low blood loss when 
compared to group-A, p-value $<0.001$.

In another research the rate of complications was compared in two groups. Two (4.7 \%) patients developed transient recurrent nerve palsy in conventional group whereas it was zero in Harmonic group. Transient hypocalcaemia developed in $48 \%$ of conventional group but only $16 \%$ in Harmonic group $(P<0.01){ }^{8}$ We observed complications in terms of hoarseness of voice and found that in $\mathrm{CH}$ group only 2 patients developed hoarseness of voice at $1^{\text {st }}$ post-operative day that resolved spontaneously therefore no indirect laryngoscopy required while in group-B none of the patients had hoarseness of voice postoperatively. There was no difference in development of hoarseness of voice in both groups, p-value $>0.05$. Moreover none of cases in either group had hoarseness of voice after $1^{\text {st }}$ post-operative day.

Postoperative pain was significantly less in the HS group $(3.89 \pm 1.07)$ compared with the $\mathrm{CH}$ group $(5.82 \pm 1.43), p$-value $<0.005$. Symptomatic hypocalcaemia was higher in $\mathrm{CH}$ when compare to HS group i.e. $6.94 \%$ and $3.60 \%$, p-vale $<0.05$. $^{9}$ In our study we found that the mean post-op pain observed at $1^{\text {st }}$ day for group B was $4.43 \pm 0.504$ and for group $A$ was $5.50 \pm 0.820$. The mean postop pain observed at $2^{\text {nd }}$ day for group $B$ was $2.93 \pm 0.583$ and for group-A it was $3.57 \pm 0.77$. The mean post-operative pain were significantly higher in conventional group at both postoperative measurements, $p$-value $<0.05$. In our study none of the patients got decreased serum calcium level. These findings are consistent with above study. A meta-analysis in 2010 reported that there is clear confirmation that utilizing the harmonic scalpel in thyroid operations is safe and effective for hemostasis with added benefit of reduction in duration of surgery. ${ }^{14}$

\section{CONCLUSION}

Through the findings of this study we found that Harmonic Scalpel gives better results in thyroid operations in terms of less operative time, less postoperative pain, less drainage volume, while no recurrent laryngeal nerve \& parathyroid injury detected in either group. So Harmonic
Scalpel can be good alternative to conventional procedure of thyroidectomy for better outcome in thyroid surgery.

Copyright @ 27 June, 2019.

\section{REFERENCES}

1. Butler D, Oltmann S. Is outpatient thyroid surgery for everyone?. Clinical Medicine Insights: Ear, Nose and Throat. 2017; 10:117955061772442.

2. Anandaravi BN, Aslam MA, Nair PP. Prospective randomised study using focus harmonic scalpel versus conventional hemostasis for vessel ligation in open thyroid surgery. International Surgery Journal. 2017; 4(4):1431-37.

3. Materazzi G, Ambrosini C, Fregoli L, De Napoli L, Frustaci $G$, Matteucci $V$ et al. Prevention and management of bleeding in thyroid surgery. Gland Surgery. 2017; 6(5):510-15.

4. Kuba B, Estrada R, Lopez H, Lauricio L. Safety and costeffectiveness in thyroidectomy using the harmonic scalpel compared to traditional hemostasis: A controlled clinical assay. Surgical technology international. 2017; 30:141-47.

5. Kilic M, Keskek M, Ertan T,Yoldas O, Bilgin A, Koc M. A prospective randomized trial comparing the harmonic scalpel with conventional knot tying in thyroidectomy. Adv Ther 2007: 24:632-38.

6. Hannan, S. A. The magnificent seven: A history of modern thyroid surgery. Int J Surg 2006 4, 187-91.

7. Ritter K, Elfenbein D, Schneider D, Chen H, Sippel R. Hypoparathyroidism after total thyroidectomy: incidence and resolution. Journal of Surgical Research. 2015; 197(2):348-53.

8. Yener O, Demir M,Yilmaz A, Yigitbasi R, Atak T. Harmonic scalpel compared to conventional hemostasis in thyroid surgery. Ind J Surg 2014:76:66-69.

9. Duan $Y$, Xue W, Zhu F, Sun D. FOCUS harmonic scalpel compared to conventional hemostasis in open total thyroidectomy - a prospective randomized study. Journal of Otolaryngology - Head \& Neck Surgery. 2013; 42(1):62.

10. Manouras A, Markogiannakis $H$, Koutras AS, Antonakis PT, Drimousis P, Lagoudianakis EE et al Thyroid surgery: comparison between the electrothermal bipolar vessel sealing system, harmonic scalpel, and classic suture ligation. Am J Surg 2008: 195:4852. 
11. Fritz D, Matthews $T$, Chandarana S, Nakoneshny $S$, Dort J. Harmonic scalpel impact on blood loss and operating time in major head and neck surgery: A randomized clinical trial. Journal of Otolaryngology Head \& Neck Surgery. 2016;45(1);58.

12. Shireen AA, Ali R, Islam ZU,Shah SH. Monopolar electrocautery versus ultrasonic dissection of the gallbladder from the gallbladder bed in laparoscopic cholecystectomy. J Ayub Med Coll Abbottabad 2013;25(3-4):16-8.
13. Miccoli P, Berti P, Dionigi GL, Agostino DJ, Orlandini C, Donatini G. Randomized controlled trial of harmonic scalpel use during thyroidectomy. Arch OtolaryngolHead \& Neck Surg.2006:132:1069-73.

14. Ecker T, Carvalho AL, Choe JH, Walosek G, Preuss KJ. Hemostasis in thyroid surgery: Harmonic scalpel versus other techniques-a meta-analysis. Otolaryngol - Head and Neck Surg. 2010: 143:17-25.

\begin{tabular}{|c|c|c|c|}
\hline \multicolumn{4}{|c|}{ AUTHORSHIP AND CONTRIBUTION DECLARATION } \\
\hline Sr. \# & Author(s) Full Name & Contribution to the paper & Author(s) Signature \\
\hline 1 & Mumtaz Ali & Data collection concersion. & \\
\hline 2 & M. Aleem-ud-Din & $\begin{array}{l}\text { Manuscript writing discussion } \\
\text { removal of plagiarism, } \\
\text { supervision of whole process. } \\
\text { Proof reading, Data analysis. }\end{array}$ & \\
\hline 4 & M. Burhan ud Din & $\begin{array}{l}\text { Data collection, Compiling of } \\
\text { results, author of result. }\end{array}$ & \\
\hline 5 & Assam Sarwar & Data analysis statistics. & \\
\hline 6 & Ansar Aslam & Compiling of references. & \\
\hline
\end{tabular}

